\title{
Evaluasi Rencana Manajemen Mutu pada Proyek Pembangunan Jembatan Rantau Kapas Tuo Tahun Anggaran 2017
}

\author{
Dj. P. Marpaung ${ }^{1}$, Annisaa Dwiretnani ${ }^{2}$, Ropiah $^{3}$ \\ Dosen Program Studi Teknik Sipil Fakultas Teknik Universitas Batanghari Jambi ${ }^{1,2}$ \\ Mahasiswa S1 Program Studi Teknik Sipil Fakultas Teknik Universitas Batanghari Jambi ${ }^{3}$ \\ e-mail: annisaa.dwiretnani@gmail.com
}

\begin{abstract}
Abstrak. Manajemen mutu konstruksi merupakan salah satu indikator kinerja penyelenggaraan pembangunan yang harus dipertanggung jawabkan, sehingga harus ditingkatkan dari waktu ke waktu. Pengendalian mutu proyek biasanya dilakukan dengan cara melakukan pengukuran-pengukuran statistik ataupun berupa ceklis-ceklis tertentu sebagai langkah evaluasi terhadap proses-proses mutu yang ingin dicapai ataupun sebagai langkah pemenuhan kriteria desain dari spesifikasi yang telah ditetapkan sebelumnya. Karena mutu salah satu poin yang paling penting dalam suatu pekerjaan, baik pekerjaan itu konstruksi atau non konstruksi. Untuk itu mutu perlu dicapai agar hasil pekerjaan tersebut baik dan bermutu. Jika pelaksanaan pekerjaan tersebut tidak mencapai mutu yang diinginkan maka mengakibatkan pengurangan kualitas dalam pengguna jasa. Tujuan dari studi ini adalah mengevaluasi dengan pendekatan proses pembangunan konstruksi yang berdasarkan Panduan Penerapan Manajemen Mutu ISO 9001:2000 dan Penerapan Spesifikasi Umum 2010 (Revisi 3) untuk Pekerjaan Konstruksi Jalan dan Jembatan Kementerian PUPR Ditjen Bina Marga pada Paket Pekerjaan Pembangunan Jembatan Rantau Kapas Tuo Tahun Anggaran 2017. Hasil analisis data dan evaluasi secara menyeluruh menunjukkan bahwa penerapan Manajemen Mutu ISO 9001:2000 berdasarkan prinsip Pendekatan Proses telah diterapkan dengan baik. Material, peralatan, dan tenaga kerja yang digunakan dalam pelaksanaan pekerjaan telah sesuai dengan pedoman teknis yaitu Spesifikasi Umum 2010 (Revisi 3) untuk Pekerjaan Konstruksi Jalan dan Jembatan Kementerian PUPR Ditjen Bina Marga.
\end{abstract}

Kata kunci: Manajemen mutu konstruksi; Pendekatan Proses; Spesifikasi Umum 2010 (Revisi 3 Bina Marga).

\section{PENDAHULUAN}

Sejarah jembatan sudah cukup tua bersamaan dengan terjadinya hubungan komunikasi/transportasi antara sesama manusia dengan alam lingkungannya. Bermacam-macam dan bentuk serta bahan yang digunakan mengalami perubahan sesuai dengan kemajuan zaman dan teknologi, mulai dari yang sederhana sekali sampai pada konstruksi yang mutakhir.

Untuk mencapai konstruksi yang aman, nyaman dan ekonomis maka perlu kita ketahui dulu bahwa manajemen mutu pekerjaan itu sendiri bagaimana dan seperti apa? Banyak sekali pekerjaan yang sudah dinyatakan selesai, maupun perkerjaan yang sedang berjalan belum dikelolah dengan baik. Sulit untuk mengecek status pekerjaan yang sedang berjalan dengan kata lain tidak biasa dimonitoring sampai tahap mana.

Manajemen mutu konstruksi merupakan salah satu indikator kinerja penyelenggaraan pembangunan yang harus dipertanggung jawabkan, sehingga harus ditingkatkan dari waktu ke waktu. Pengendalian mutu proyek biasanya dilakukan dengan cara melakukan pengukuran-pengukuran statistik ataupun berupa ceklis-ceklis tertentu sebagai langkah evaluasi terhadap proses-proses mutu yang ingin dicapai ataupun sebagai langkah pemenuhan kriteria desain dari spesifikasi yang telah ditetapkan sebelumnya.

Sesuai data dari Dinas Pekerjaan Umum dan Penataan Ruang Kabupaten Batanghari di tahun 2017. Saat ini pekerjaan konstruksi untuk APBD di Kabupaten Batanghari belum semua masyarakat bisa menikmati sarana transportasi yang baik, ada 155 jembatan kayu yang tersebar di delapan Kecamatan, untuk saat ini tinggal 14 jembatan yang belum dibangun secara permanen. Dari total jumlah jembatan di kabupaten itu, sekitar 90 persen sudah dibangun permanen guna mempermudah akses transportasi masyarakat dan salah satunya jembatan yang menghubungkan Desa Rantau Kapas Tuo dan desa Rantau Kapas Mudo maupun Desa-desa disekitarnya. Dilihat dari kondisi yang ada, sudah tidak layak digunakan, maka sangat penting Pembangunan Jembatan Rantau Kapas Tuo tersebut diadakan, karena sebagian besar masyarakat Desa Rantau Kapas Tuo dan Desa Rantau Kapas Mudo mata pencariannya adalah petani atau berkebun sawit dan karet. Untuk mengangkut hasil pertanian tersebut maka masyarakat Desa Rantau Kapas Tuo maupun Desa-desa disekitarnya sangat menginginkan sarana transportasi yang baik aman dan nyaman.

Tujuan dari penelitian ini adalah untuk mengevaluasi rencana manajemen mutu Pada Paket Pekerjaan Pembangunan Jembatan Rantau Kapas Tuo Tahun Anggaran 2017. Pengendalian mutu merupakan lingkup kecil dari manajemen mutu. Objek pekerjaan dievaluasi dengan prinsip pendekatan proses pembangunan konstruksi yang berdasarkan Panduan Penerapan Manajemen Mutu ISO 9001:2000 (2005:13) dan penerapan pedoman teknis Spesifikasi Umum 2010 (Revisi 3) untuk Pekerjaan Konstruksi Jalan dan Jembatan Kementerian PUPR Ditjen Bina Marga. 
Pekerjaan konstruksi merupakan pekerjaan yang berkaitan dengan pembangunan suatu bangunan infrastruktur yang umumnya mencakup pekerjaan pokok yang termasuk dalam bidang teknik sipil dan arsitektur. Selain itu, juga melibatkan bidang ilmu lain-nya, seperti teknik industri, mesin, elektro, geoteknik, geodesi, lanskap. Tahapan pekerjaan konstruksi dimulai sejak munculnya prakarsa pembangunan, yang selanjutnya ditindaklanjuti dengan survey dan seterusnya, hingga konstruksi benar-benar berdiri dan dapat dioperasikan sesuai dengan tujuan fungsionalnya. Dalam pekerjaan konstruksi dilaksanakan hanya satu untuk satu kegiatan atau paket pekerjaan, setiap pekerjaan mempunyai jangka waktu, biaya, sumber daya manusia untuk melaksanaan pekerjaan tersebut. Selain itu pekerjaan konstruksi ini melibatkan berbagai pihak-pihak yang terkait.

Menurut Undang-Undang Republik Indonesia Nomor 2 Tahun 2017 pasal 2 Tentang Jasa Konstruksi, ialah Jasa Konstruksi berlandaskan pada asas kejujuran dan keadilan, manfaat, keserasian, keseimbangan, kemandirian, keterbukaan, kementrian, keamanan dan keselamatan demi kepentingan masyarakat, bangsa dan Negara.

Menurut buku Panduan Penerapan Manajemen Mutu ISO 9001:2000 (2005: 13) ada 8 (delapan) Prinsip Manajemen Mutu dimana prinsip manajemen mutu merupakan metode bagaimana cara memimpin, mengatur dan mengendalikan sesuatu organisasi atau Badan Usaha. Dengan Prinsip-prinsip manajemen itu SMM (Sistem Manajemen Mutu) dapat dioperasikan secara konsisten, sistematis dan transparan. Keberhasilan badan usaha dalam meningkatkan keuntungan dan pengembangan pasar dapat dihasilkan dengan menerapkan dan memelihara suatu sistem manajemen mutu yang dirancang untuk memenuhi persyaratan dari semua pihak yang berkepentingan, dan secara terus-menerus meningkatkan kinerjanya. Kedelapan prinsip manajemen dikenal dan diuraikan dalam penjelasan seri ISO. Prinsip manajemen perlu dipahami oleh seluruh badan usaha. Berikut diuraian 8 prinsip manajemen mutu dalam seri ISO 9001:2000.

\section{Fokus Pelanggan}

Kehidupan Badan Usaha tergantung pada pelanggannya. Oleh karena itu Badan Usaha tergantung memahami harapan dan kebutuhan pelanggan. Badan Usaha harus merencanakan dan memenuhi pelanggan dan mencoba untuk melebihi harapan kebutuhan saat ini dan yang akan datang.

Prinsip ini terkait dengan klausul-klausul ISO 9001:2000. Tujuannya untuk mengatur sistem mutu, kebijakan, sasaran, perencanaan, kesadaran, produksi atau proyek dan penyedian jasa, memantau kepuasan pelanggan dan peningkatan yang berkelanjutan. Prinsip ini telah diakomodasikan dengan mempunyai klausul tersendiri yaitu klausul 1. Fokus Pelanggan.

2. Kepemimpinan

Manajemen puncak yaitu Direktur Badan Usaha harus menetapkan suatu kebijakan mutu dan sasaran mutu Badan Usaha untuk memberi arahan dan target Badan Usaha Direktur Badan Usaha menciptakan suatu lingkungan yang harmonis dengan melibatkan staf dan karyawan dalam mencapaikan sasaran mutu Badan Usaha.

Prinsip ini terkait di dalam standar ISO 9001:2000 klausul-klausul untuk komitmen manajemen, fokus pelanggan, kebijakan mutu, sasaran mutu, tanggung jawab manajemen, wakil manajemen, komunikasi internal dan tinjauan manajemen.

3. Pelibatan Karyawan

Badan Usaha harus mampu melibatkan semua karyawan untuk meningkatkan kepedulian karyawan terhadap pencapaian mutu dan kepuasan pelanggan, dan menciptakan lingkungan kerja yang kondusip dan mampu memenuhi persyaratan pelanggan.

Orang-orang yang berada semua tingkat perlu dilibatkan dalam memenuhi kebutuhan pelanggan. Yang terlibat penuh dapat menerapkan kemampuan yang berguna demi kepentingan Badan Usaha, Karyawan, Rekan kerja dan pelanggan. Komunikasi antar pihak harus dituliskan, dan proses pekerjaan atau jasa harus dikerjakan sesuai dengan prosedur yang diterapkan.

Terkait dengan standar ISO 9001:2000 menjelaskan komitmen manajemen, kebijakan mutu, sasaran mutu, tanggung jawab dan wewenang. Kesadaran kemapuan/wewenang dan pelatihan komunikasi internal dan lingkungan pekerjaan.

4. Pendekatan Proses

Badan Usaha harus mampu menciptakan kondisi bahwa yang ingin dicapai akan lebih efisien jika aktivitas dan sumber daya yang terkait diatur sebagai sebuah proses. Pendekatan proses harus dipusatkan pada pengendalian masukan ke dalam proses dan pencegahan ketidak sesuaian atau kesalahan dalam pekerjaan.

Sistem manajemen mutu diterapkan berdasarkan pendekatan proses yang diawali dengan indentifikasi dan penetapan kriteria yang akan menjadi kendali setiap tahapan proses. Keberhasilan pencapaian mutu sangat bergantung pada konsistensi produk yang bermutu dan memenuhi persyaratan pelanggan.

Klausul-klausul yang terkait dengan prinsip pendekatan proses diantaranya adalah perencanaa SMM, realisasi produk, perbaikan berkelanjutan, pengendalian produk yang tidak sesuai (cacat), tindakan koreksi dan tindakan pencegahan. 
5. Pendekatan Sistem pada Manajemen

Badan Usaha harus merencanakan cara memenuhi persyaratan pelanggan, Rencana meliputi semua aktivitas yang terkaitan dengan mutu dari hubungan awal pelanggan hingga serah terima pekerjaan dan memantau kepuasan pelanggan. Mengindetifikasi, memahami dan mengelolah proses yang saling berhubungan ini, sebagai sebuah sistem, yang berperan untuk mencapai sasaran yang efektif dan efisien bagi Badan Usaha. Pengendalian atas mata rantai dan Interface proses yang terlibat adalah paling untuk manajemen yang baik.

Klausul-klausul ISO 9001:2000 yang mengambarkan pendekatan sistem untuk manajemen yang diuraikan di atas terdapat pada pasal persyaratan umum, dalam persyaratan dokumentasi, manual mutu, perencanaan sistem manajemen mutu, pengendalian dokumen dan arsip, komunikasi internal, tinjauan ulang manajemen, perencanaan realisasi produk, idetifikasi dan kemapuan telusur, pemeliharaan produk dan perbaikan berkesenambungan.

6. Perbaikan Berkesinambungan

Badan Usaha harus mampu mengarahkan semua karyawan yang terlibat para pimpinan dan karyawan harus belajar dari kesalahan dan permasalahan dan secara terus -menerus meningktan sistem yang telah dibangun peningkatan yang berkesinambungan keseluruhan kinerja Badan Usaha merupakan bagian sasaran utama.

Perbaikan berkesinambungan yang telah diuraikan dan telah dijelsakan persyaratan ISO 9001:2000 pada pasal persyaratan umum, persyaratan dokumentasi, komitmen manajemen, kebijakan mutu, sasaran hasil mutu, wakil manajemen, pengawasan internal analisa data, tindakan pencegahan, tindakan koreksi dan tindakan perbaikan.

7. Pendekatan Fakta untuk Membuat Keputusan

Harus mampu membangun paradigma dalam diri karyawannya, seperti keputusan yang efektif harus berdasarkan analisa data dan informasi. Informasi dan data serta sistem harus dibuat. Informasi dikumpulkan dalam suatu data yang tidak bisa dan bermakna satu, sehingga jalur komunikasi yang jelas adalah penting. Klausul-klausul ISO 9001:2000 yang menyertai sasaran mutu, sistem manajemen mutu, perencanaan, wakil manajemen, komunikasi internal, tinjauan manajemen, pengendalian alat pengukur dan monitoring, kepuasan pelanggan, audit internal dan peningkatan yang berkesinambungan pelangan, audit internal dan peningkatan yang berkesinambungan.

8. Hubungan Pemasok yang Saling Menguntungkan.

Badan Usaha harus mampu membangun lingkungan usaha yang saling menguntungkan antara Badan Usaha dan pemasokannya. Hubungan pelanggan dan pemasokan tergantung pada hubungan satu sama lain yang saling menguntungkan, dan akan menghasilkan keuntungan bagi semua pihak, seperti peningkatan mutu, stabilitas dan konsisten yang ditingkatan.

Hubungan dimulai dengan komunikasi yang jelas dan dibangun berdasarkan konsisten tujuan dan kepercayaan. Klausul-klausul ISO 9001:2000 yang terlibat dengan prinsip ini terdapat dalam pasal persyaratan umum, sasaran mutu, perencanaan, sistem manajemen mutu, pembelian, penyedian produk pemantau, peningkatan produk dan proses analisa data, tindakan pencegahan, koreksi dan peningkatan yang berkesinambungan.

Dari 8 prinsip tersebut bisa dilihat bagian mana saja yang paling peting untuk manajemen mutu baik dari Badan Usaha sampailah hubungan pemasok. Untuk itu perlu kita telitikan dari 8 prinsip manajemen mutu tersebut yang akan dituangkan dalam penelitian ini adalah butir 4. Pendekatan Proses, karena sesuai dengan judul penelitian yaitu "Evaluasi Rencana Manajemen Mutu pada Proyek Pembangunan Jembatan Rantau Kapas Tuo Tahun Anggaran 2017".

Tahapan kegiatan konstruksi dimulai sejak munculnya prakarsa pembangunan, yang selanjutnya ditindaklanjuti dengan survey dan seterusnya, hingga konstruksi benar-benar berdiri dan dapat dioperasikan sesuai dengan tujuan fungsionalnya.

Dari buku Manajemen Konstruksi (2013:26) Suatu pekerjaan dibagi menjadi beberapa tahapan untuk menjaga kesesuaian hubungan pada kegiatan operasional pihak-pihak yang terkait dalam pelaksanaannya. Hal tersebut terintegrasi menjadi suatu bentuk siklus kehidupan pekerjaan yang mencakupi:

1. What - Teknik apa yang dilakukan

2. When - Kapan deliverables dicapai dan bangaimana ditinjau divalidasi

3. Who - Siapa yang terlibat

4. Why - Mengapa perlu manajemen mutu

5. How - Bagaimana mengontrol dan menyetujui.

Tahapan dalam proyek konstruksi dibagi menjadi beberapa tahap yaitu:

a. Tahap konseptual atau tahap kelayakan

b. Tahap Perencanaan dan Desain

c. Tahap Produksi/Pelaksanaan/Konstruksi

d. Tahap Serah Terima/Operasional 


\section{METODE}

Jenis penelitian dalam studi adalah penelitian kualitatif yang merupakan penelitian yang lebih mengutamakan pada masalah proses dan makna/persepsi, tujuan utamanya adalah untuk memperoleh wawasan tentang topik tertentu. Teknik yang digunakan wawancara dan observasi, melalui metode ini peniliti akan menganalisis data yang didapatkan dari lapangan dengan detail. Penilitian tidak dapat meriset kondisi sosial yang diobservasi, karena seluruh realitas yang terjadi merupakan kesatuan yang terjadi secara alami. Hasil penelitian kualitatif juga dapat memunculkan teori atau konsep baru apabila hasil penelitiannya bertentangan dengan teori konsep yang sebelumnya dijadikan kajian dalam penelitian.

Dalam penelitian ini tipe pendekatan yang digunakan adalah tipe studi kasus. Peneliti mengeksplorasi suatu masalah dengan batasan terperinci, dengan pengambilan data yang mendalam, dan menyertakan berbagai sumber informasi. Penelitian ini dibatasi oleh waktu dan tempat, dan kasus yang dipelajari berupa program, peristiwa, aktivitas, atau individu.

\section{Peta Lokasi Proyek}

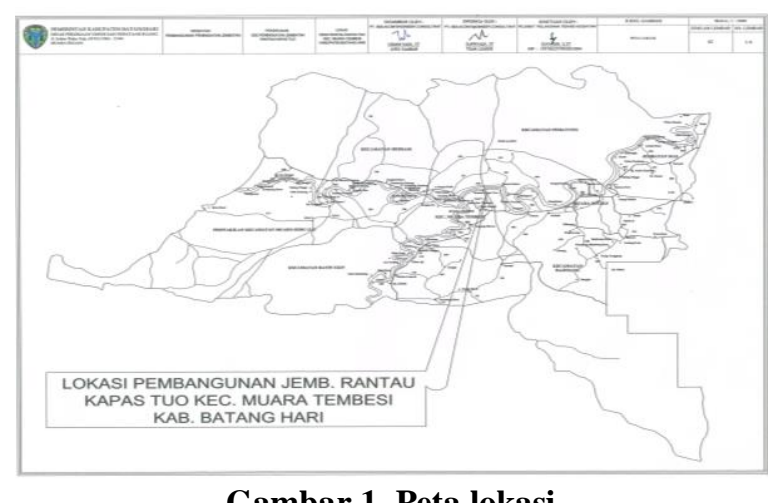

Gambar 1. Peta lokasi

Sumber: PT. Sidlacom Engineer Consultant (2017)

Untuk mendapatkan data-data yang valid dan obyektif terhadap apa yang diteliti maka kehadiran peneliti dilapangan dalam penelitian kualitatif mutlak diperlukan. Kehadiran peneliti sebagai pengamat langsung terhadap kegiatan-kegiatan yang akan diteliti sangat menentukan hasil penelitian, maka dengan cara riset lapangan sebagai pengamat penuh secara langsung pada lokasi penelitian peneliti dapat menemukan dan mengumpulkan data secara langsung. Penulis juga mempelajari data-data yang ada di dalam Laporan Bulanan dan Laporan Akhir Pekerjaan Pembangunan/ Peningkatan Jembatan Rantau Kapas Tuo kemudian mengambil data-data atau temuan apa saja yang dapat dibandingkan dengan sebuah dokumen atau referensi yang dijadikan sebagai acuan atau mengimplementasikannya berdasarkan acuan yang digunakan sebagai bentuk langkah-langkah pengendalian mutu dalam pelaksanaan proyek tersebut. Dalam hal ini penulis kemudian menentukan bagian yang akan dideskripsikan lebih jauh adalah mengenai:

1. Narasi Kegiatan Kontaktor, Permasalahan dan Solusi

2. Ringkasan Test Kuat Tekan Beton

3. Ringkasan Jaminan Mutu

Acuan yang digunakan adalah pedoman teknis yaitu Spesifikasi Umum 2010 (Revisi 3) untuk Pekerjaan Konstruksi Jalan dan Jembatan Kementerian PUPR Ditjen Bina Marga dan Standar Internasional ISO 9001:2000 Sistem Manajemen Mutu - Persyaratan.

\section{Data Umum}

Tabel 1. Data Kontrak Penyedia Jasa Konstruksi

\begin{tabular}{|c|c|c|}
\hline 1. & Pengguna Jasa & $\begin{array}{l}\text { Dinas Pekerjaan Umum dan Penataan Ruang Bidang Bina Marga } \\
\text { Kabupaten Batang Hari }\end{array}$ \\
\hline 2. & Nama Kegiatan & Pembangunan/Peningkatan Jembatan \\
\hline 3. & Nama Pekerjaan & Peningkatan Jembatan Rantau Kapas Tuo \\
\hline 4. & Lokasi Kegiatan & Kabupaten Batang Hari \\
\hline 5. & Pejabat Pelaksana Teknis Kegiatan (PPTK) & SUYAKUN, S.ST \\
\hline 6. & Sumber Dana & APBD Kab. Batang Hari Tahun Anggaran 2017 \\
\hline 7. & Penyedia Jasa/Kontraktor & PT. MANGGALA MEGA KARYA \\
\hline 8. & No. /Tanggal Kontrak & 630/19/KONT/PUPR-BM/2017 Tanggal 12 Juli 2017 \\
\hline 9. & No./Tanggal SPMK & 630/19/SPMK/PUPR-BM/2017 Tanggal 12 Juli 2017 \\
\hline 10. & Nilai Kontrak & Rp. 5.620.255.000,- (Termasuk PPN 10\%) \\
\hline
\end{tabular}


Dj. P. Marpaung et al, Evaluasi Rencana Manajemen Mutu pada Proyek Pembangunan Jembatan Rantau Kapas Tuo Tahun Anggaran 2017

11. Jangka Waktu Pelaksanaan

12. Masa Pemeliharaan

13. Tanggal Rencana PHO

14. Direktur Utama
150 (Seratus Lima Puluh) Hari Kalender 180 (Seratus Delapan Puluh) Hari Kalender 08 Desember 2017 USMAN

Sumber: PT. Manggala Mega Karya (2017)

\section{HASIL}

Menjaga kualitas material kontruksi merupakan hal yang sangat penting. dengan adanya kualitas maka material dapat dijaga dengan baik dan akan menghasilkan kualitas material konstruksi yang tinggi pula karena material sangat berperan penting dalam konstruksi yang akan dibangun. Untuk mendapatkan hasil yang baik dan berkualitas yang tinggi maka material yang akan digunakan terlebih dahulu diuji laboratorium sesuai dengan peraturan-peraturan atau spesifikasi teknis yang berlaku.

Dalam pembahasan ini yang akan dibahas dimulai dari divisi 3 Pekerjaan tanah, divisi 7 pekerjaan struktur beton mutu sedang $f_{c}{ }^{\prime} 20 \mathrm{MPa}$, divisi 7.3 Baja tulangan U 24 dan U 32, divisi 7.4 baja struktur Bj $50 \mathrm{MPa}$, dan divisi 7.6 pemancangan tiang pancang baja diameter $400 \mathrm{~mm}$, sebagai berikut:

\section{Divisi 3. Pekerjaan Tanah}

Pekerjaan ini mencakup pengadaan, pengangkutan, penghamparan dan pemadatan tanah atau bahan berbutir yang disetujui untuk pembuatan timbunan. pada pekerjaan tanah timbunan ini dilakukan pada akhir pekerjaan dan dilakukan pemadatan. Tanah timbunan adalah material yang akan digunakan untuk timbunan dan pemadatan dilapangan, agar pekerjaan tanah timbunan tidak menimbulkan kerugian dalam kegiatan konstruksi maka dilakukan pemadatan yang berdasarkan jenis tanah yang akan diambil untuk bahan timbunan.

Sebelum dilakukan pemadatan tanah maka tanah yang akan diambil untuk tanah timbunan tersebut diuji terlebih dahulu agar memenuhi spesifikasi teknis pekerjaan. Tanah timbunan yang digunakan dalam pekerjaan Pembangunan Jembatan Rantau Kapas Tuo ini berlokasi di Muaro Tembesi Desa Rantau Kapas Mudo Kabupaten Batanghari. Untuk hasil pengujian tanah timbunan dapat dilihat pada Tabel 2. dan tabel 3. dangan ringkasan hasil pemeriksaan tanah timbunan biasa sebagai berikut:

Tabel 2. Data Hasil Analisa Saringan

\begin{tabular}{cccccc}
\hline Nomor saringan & $3 / 4 "$ & No. 4 & No. 10 & No. 40 & No. 200 \\
\hline \% Lolosan Saringan & 100 & 100 & 79 & 67,34 & 40,36 \\
\hline
\end{tabular}

Sumber: Laporan Akhir PT. Sidlacom E. C. (2017)

Tabel 3. Data Hasil Pemeriksaan Tanah

\begin{tabular}{|c|c|c|}
\hline Pemeriksaan Laboratorium & Hasil Pemeriksaan & Spesifikasi \\
\hline \multicolumn{3}{|l|}{ Pengujian Pemadatan: } \\
\hline Berat Isi Kering $(M D D)$ & $1,547 \mathrm{Gr} / \mathrm{Cc}$ & - \\
\hline Kadar Air $(O M C)$ & $18,10 \%$ & - \\
\hline \multicolumn{3}{|l|}{ Konsistensi Atterbrerg: } \\
\hline Liquid Limit & $31,02 \%$ & Max. $20 \%$ \\
\hline Plastis Limit & $18,63 \%$ & - \\
\hline Plastis Indek & $12,38 \%$ & $25 \%$ \\
\hline \multicolumn{3}{|l|}{ Nilai C.B.R. Rendaman } \\
\hline rd. Optimum. CBR & $6,57 \%$ & \\
\hline rd. $95 \% C B R$ & $5,48 \%$ & - \\
\hline rd. $90 \% C B R$ & $4.00 \%$ & \\
\hline Berat Isi Gembur & $1,223 \mathrm{Gr} / \mathrm{Cc}$ & \\
\hline Berat Isi Padat & $1,398 \mathrm{Gr} / \mathrm{Cc}$ & \\
\hline Berat Jenis Tanah & 2,341 & \\
\hline Klasifikasi Tanah & A-7-5 & \\
\hline Harga Minimum Untuk C.B.R & $6,57 \%$ & Min. $6 \%$ \\
\hline
\end{tabular}

Sumber: Laporan Akhir PT. Sidlacom E. C. (2017)

Dari tabel diatas diketahui bahwa Pekerjaan tanah timbunan sudah melalui uji laboratorium yang menunjukan bahwa Klasifikasi tanah A-7-5 atau tanah berjenis lempung berbutir halus dengan hasil CBR 6,57\%. Untuk menentukan kadar air pada tanah timbunan tersebut maka dilakukan test Modified dengan hasil kadar air optimum moisture content (OMC) 18,10\% dan berat isi kering maximum dry density (MDD) 1,547 Gr/Cc. 
Pemadatan dilakukan dengan cara penghamparan tanah per 20-30 $\mathrm{cm}$ dan di setiap penghamparan dilakukan pemadatan dengan alat vibratory roller 5-8 Ton. untuk bagian yang tidak bisa dilakukan alat vibratory roller pemadatan tanah dilakukan dengan alat vibrating rammer agar pemadatan terpenuhi disetiap sisi.

Setelah dilakukan pemadatan pekerjan selanjutnya dilakukan dengan uji kepadatan lapangan dengan sand cone. Agar pekerjaan pemadatan dilakukan dengan benar dan sesuai dengan perintah Direksi Pekerjaan. Untuk hasil pemadatan dapat dilihat pada Tabel 4. ringkasan hasil pemeriksaan kepadatan lapangan sebagai berikut:

Tabel 4. Ringkasan Hasil Pemeriksaan Kepadatan Lapangan

\begin{tabular}{c|c|c|c|c|c}
\hline No. & STA/Abutment & L/CL/R & $\gamma_{\text {d Lab (\%) }}$ & $\gamma_{\text {d Lap (\%) }}$ & Nilai Kepadatan (\%) \\
\hline A. & Tanah Timbunan Abutmen 1 & \multicolumn{1}{c}{} & \\
\hline 1. & STA 0+012 & CL & 1,547 & 1,471 & 95,11 \\
2. & STA 0+020 & CL & 1,547 & 1,474 & 95,28 \\
3. & STA 0+015 & CL & 1,547 & 1,550 & 100,19 \\
4. & STA 0,+022 & CL & 1,547 & 1,552 & 100,32 \\
\hline B. & Tanah Timbunan Abutmen 2 & \multicolumn{5}{c}{} \\
\hline 5. & STA 0+012 & CL & 1,547 & 1,472 & 95,17 \\
6. & STA 0+020 & CL & 1,547 & 1,475 & 95,32 \\
7. & STA 0+015 & CL & 1,547 & 1,549 & 100,16 \\
8. & STA 0,+022 & CL & 1,547 & 1,552 & 100,32 \\
\hline
\end{tabular}

Sumber: Laporan Akhir PT. Sidlacom E. C. (2017)

Untuk pekerjaan tanah timbunan ini memiliki volume berdasarkan kontrak 1.450,400 $\mathrm{m}^{3}$. Ketelambatan pekerjaan tanah timbunan ini dikarenakan penyedian baja BJ 50 terlambat datang ke lokasi dan dikarenakan lokasi sulit untuk masuknya mobil penghatar barang sehingga barang-barang tersebut diangkut satu persatu dan sebagian dibantu dengan alat bantuan semacam katrol untuk menarik barang-barang yang akan digunakan, beberapa hal ini yang menyebabkan pekerjaan tanah harus tertunda dan pekerjaan lainnya juga.

Pekerjaan tanah timbunan mulai diminggu ke-29 (dua puluh sembilan) disaat pekerjaan tanah berlangsung ada beberapa bagian yang bisa mengikuti gambar dan ada juga berubah dikarenakan bagian kiri dan bagian kanan abutmen jembatan tersebut dikelilingi oleh rumah penduduk sehingga volume pekerjaan tanah timbunan berubah dan pekerjaan tanah timbunan sebagian timbunan menutupi halaman rumah warga sekitar. Maka dari itu terjadilah CCO yang mengikuti kondisi lapangan sehingga pekerjaan tanah timbunan berkurang menjadi 1.181,369 $\mathrm{M}^{3}$ yang berdasarkan Adendum No. 01 dari kondisi lapangan inilah penyebab utama terjadi CCO.

\section{Divisi 7.1.(7) Pekerjaan Struktur Beton Mutu Sedang $f c^{\prime} 20$ MPa}

Yang dimaksud dengan beton adalah campuran antara semen portland atau semen hidraulik yang setara, agregat halus, agregat kasar, dan air dengan atau tanpa bahan tambahan yang akan membentuk massa padat. Untuk mencapai mutu beton yang akan digunakan maka sebelum dilakukan pengecoran kontraktor (PT. Manggala Mega Karya) membuat DMF (Design Mix Formula) di Laboratorium. Material yang digunakan sesuai dengan spesifikasi teknis yang berlaku. Hasil DMF (Design Mix Formula) yang digunakan dilapangan, dapat dilihat seperti dibawah ini:

Tabel 5. Data Campuran Bahan-Bahan Material

\begin{tabular}{llcc}
\hline \multicolumn{1}{c}{ Ukuran untuk pelaksanaan dilapangan: } & \multicolumn{1}{c}{ Ukuran } & Berat Kg & Volume Dm $^{3}$ \\
\hline Semen Padang Type 1 & Semen & 50 & 40.0 \\
Agg. Halus (Pasir Ex. Sei. Batanghari) & Agg. Halus & 69,21 & 48.0 \\
Agg. Kasar (Bt. Split 1-2) & Agg. Kasar Bt. Split 1-2 & 57,01 & 40.3 \\
Agg. Kasar (Bt. Split 2-3) & Agg. Kasar Bt. Split 2-3 & 101,83 & 74.4 \\
& Air & 26,21 & 26.2 \\
\hline
\end{tabular}

Sumber: Laporan Akhir PT. Sidlacom E. C. (2017)

Tabel 6. Data Gradasi Campuran

\begin{tabular}{|c|c|c|c|c|c|c|c|c|c|c|}
\hline No & Ukuran Saringan & $11 / 2 "$ & $3 / 4 "$ & $3 / 8^{\prime \prime}$ & No. 4 & No. 8 & No. 16 & No. 30 & No. 50 & No. 100 \\
\hline 1 & Agg. Halus & 100 & 100 & 100 & 95,00 & 77,96 & 63,40 & 50,10 & 32,35 & 2,98 \\
\hline 2 & Agg. Kasar (Bt. Split 1-2) & 100 & 92,92 & 20,95 & 7,52 & 2,73 & 1,10 & 0,95 & 0,33 & 0,01 \\
\hline 3 & Agg. Kasar (Bt. Split 2-3) & 100 & 41,89 & 44,70 & 4,13 & 1,56 & 1,32 & 0,72 & 0,51 & 0,43 \\
\hline 4 & Agg. Gabungan & 100 & 71,31 & 44,49 & 32,51 & 25,00 & 20,08 & 15,74 & 10,11 & 1,10 \\
\hline 5 & Batasan Agg. Gabungan & 100 & $75-50$ & $60-63$ & $47-24$ & $38-18$ & $30-12$ & $23-7$ & $15-3$ & $0-5$ \\
\hline
\end{tabular}

Sumber: Laporan Akhir PT. Sidlacom E. C. (2017) 
Dj. P. Marpaung et al, Evaluasi Rencana Manajemen Mutu pada Proyek Pembangunan Jembatan Rantau Kapas Tuo Tahun Anggaran 2017

Tabel 7. Data Campuran Percobaan

\begin{tabular}{clcc}
\hline No. & \multicolumn{1}{c}{ Uraian } & Satuan & Percobaan \\
\hline 1. & Faktor Air Semen & & 0,5445 \\
2. & Kadar Semen & $\mathrm{Kg} / \mathrm{M}^{3}$ & 386,2 \\
3. & Slump & $\mathrm{Cm}$ & $7,8 \pm 2$ \\
4. & Berat Isi Beton & $\mathrm{Kg} / \mathrm{M}^{3}$ & 2,346 \\
5. & Kuat Tekan Beton & & \\
& $-\quad$ Umur 3 Hari & $\mathrm{Kg} / \mathrm{Cm}^{3}$ & 153 \\
& $-\quad$ Umur 7 Hari & $\mathrm{Kg} / \mathrm{Cm}^{3}$ & 237,1 \\
\hline
\end{tabular}

Sumber: Laporan Akhir PT. Sidlacom E. C. (2017)

Dari tabel diatas dapat kita lihat material yang digunakan telah uji sesuai dengan spesifikasi teknis yang berlaku. Agar material tetap terjaga maka penyedia jasa sangat memperhatikan komposisi campuran disaat pengecoran. Dan disaat pengecoran terjadi, penyedia jasa tidak mengunakan Truck Mixer disebabkan kondisi lapangan tidak bisa masuk truk tersebut maka pihak penyedia jasa mengunakan alat bantu Concrete Mixer 0,3-0,6 $\mathrm{m}^{3}$ dan alat yang mendukung lainya.

Untuk menjaga mutu dari material yang akan digunakan terlebih dahulu material dibersihkan dengan cara penyiram air ke material yang akan digunakan dan takaran-takaran material telah mengikuti sesuai dengan DMF. Disaat pengecoran berlangsung untuk menguji kekentalan beton segar tersebut maka dilakukan uji slump test yang telah direncanakan dengan ukuran 7,8 $2 \mathrm{~cm}$. Setelah melakukan slump test lalu pengambilan sampel kubus dengan ukuran 15 x 15 x $15 \mathrm{~cm}$.

Pengambilan sampel dilakukan secara acak sehingga mutu beton dapat diketahui disetiap pengecoraan, pengambilan sampel diambil 6 sampel. Setelah pengambilan sampel di umur 3 hari dan 7 hari dilakukan uji kuat tekan disetiap sampel agar mengetahui kuat beton yang ingin dicapai. Dikarenakan pengecoran telambat maka pihak-pihak yang bersangkutan telah setuju akan pengambilan kuat tekan di umur 3 hari dan 7 hari. Untuk mengetahui umur beton 28 hari itu pihak yang bersangkutan memprediksi kuat tekan dari umur 3 hari dan 7 hari.

Setelah melihat hasil dari uji kuat tekan yang dihasilkan oleh sampel kubus tersebut. Untuk membuktikan beton yang ada dilapangan terpenuhi atau tidak mutu yang dicapai maka alat hammer test merupakan alat yang akan membutikan bahwa beton yang ada dilapangan merupakan beton mutu sedang dengan $f_{c}$ ' $20 \mathrm{MPa}$.

Berdasarkan kontrak volume $f_{c}$ ' $20 \mathrm{MPa}$ adalah 491,890 $\mathrm{m}^{3}$ dikarenakan volume tiang pancang lebih kecil dari rencana maka pihak-pihak yang bersangkutan setuju akan dipindahkan ke pekerjaan rigid pavement yang menyebabkan beton mutu sedang ini bertambah dan material yang mendukung rigid pavement juga mengalami penambahan volume. Sehingga beton mutu sedang ini bertambah menjadi 505,830 $\mathrm{m}^{3}$ yang berdasarkan Adendum No. 01. Divisi 7.3 Baja Tulangan U 24 Polos dan U 32 Ulir

Pekerjaan ini harus mencakup pengadaan dan pemasangan baja tulangan sesuai dengan Spesifikasi dan gambar, atau sebagaimana yang diperintahkan oleh Direksi Pekerjaan. Untuk pekerjaan baja tulangan U 24 digunakan dilapangan dimulai besi diameter $16 \mathrm{~mm}$ kebawah sedangkan U 32 digunakan besi diameter $19 \mathrm{~mm}$ sampai besi diameter $25 \mathrm{~mm}$ dengan kebutuhan yang ada didalam gambar kerja. Dari laporan konsultan diketahui untuk baja tulangan $\mathrm{U} 24$ sesuai dengan hasil uji laboratorium atau pabrik yang memproduksinya.

Untuk besi U 24 polos yang digunakan memiliki volume berdasarkan kontrak 11.536,430 $\mathrm{Kg}$, berdasarkan addendum No. 01 8.999,058 Kg. Rencana pekerjaan U 24 polos ini mulai minggu ke-17 (tujuh belas) dan berakhir minggu ke-25 (dua puluh lima). Secara realisasi dilapangan minggu ke-14 (empat belas) dan berakhir minggu ke-32 (tiga puluh dua).

Baja tulangan U 32 ulir memiliki volume berdasarkan kontrak 26.874,290 Kg, berdasarkan addendum No. 01 bertambah menjadi $28.430,605 \mathrm{Kg}$. Dalam time schedule jadwal rencana pekerjaan dimulai minggu ke-13 (tiga belas) dan berakhir minggu ke-25 (dua puluh lima). Realisasi dilapangan minggu ke-8 (delapan) dan berakhir minggu ke-32 (tiga puluh dua).

\section{Divisi 7.4 Baja Struktur BJ 50}

Yang dimaksud dengan baja struktur adalah bahan jembatan baja seperti gelagar baja komposit termasuk komponen gelagar baja komposit seperti balok, baut, ring, diafragma yang digunakan sebagaimana suatu komponen konstruksi jembatan. Pekerjaan ini juga akan mencakup penyediaan, fabrikasi, pemasangan, galvanisasi dan pengecatan logam struktur sebagaimana yang disyaratkan dalam spesifikasi teknis atau sebagimana yang ditunjukkan dalam gambar.

Pada pekerjaan baja struktur BJ 50 di gunakan gelagar baja komposit kelas B, bahan yang digunakan telah diuji secara laporan uji mekanik yang diambil dari PT. Biro Klasifikasi Indonesia (Persero) dan hasil uji tariknya dengan nilai kuat tarik T-1 55,44 Kgf $/ \mathrm{mm}^{2}$ dan T-2 55,06 Kgf/mm². Pada penyediaan material baja struktur ini tidak ada di 
Jambi maka pihak kontraktor memesan material di luar Pulau Sumatra, dikarenakan memesan ditempat yang dapat dipercaya maka penyedia material baja struktur tersebut kesulitan melayani berbagai pemesanan sehingga pesanan yang dari pihak PT. Manggala Mega Karya pun telambat dikirim dari pabrikan. Hal inilah yang menyebabkan semua pekerjaan yang akan dikerjaan mengalami keterlambatan. Sehingga penyedia baja struktur BJ 50 datang diminggu ke15 (lima belas). Ketika material datang ke lokasi juga mengalami hambatan kecil karena truck pengakut material baja tidak bisa masuk atau menghantar ke lokasi yang ditunju sehingga truck hanya bisa mengantar material tersebut hanya sampai di dekat trowongan sebelum masuk lokasi. Untuk mengatasi masalah tersebut maka pihak penyedia jasa menyarankan menggunakan alat bantu untuk mengangkut material tersebut dangan alat katrol dan sebagian tenaga kerja juga ikut membantu mengangkut material baja BJ 50 tersebut.

Pekerjaan baja struktur BJ 50 (titik leleh $290 \mathrm{MPa}$ ) dengan volume penyediaan bahan 34.483,280 Kg dan bobot pekerjaan 24,666 \%. Pada pekerjaan baja struktur BJ 50 ini tidak mengalami CCO hanya saja mengalami penambahan waktu yang cukup banyak untuk mengatasi masalah-masalah yang berhubungan dengan material baja BJ 50 ini.

\section{Divisi 7.6 Pemancangan Tiang Pancang Baja Diameter $400 \mathrm{~mm}$}

Yang dimaksud dengan Pondasi Tiang adalah komponen struktur berupa tiang yang berinteraksi langsung dengan tanah, yang berfungsi sebagai penopang akhir dan menyalurkan beban dari struktur jembatan ke tanah. Tiang pancang baja struktur berupa profil baja dilas biasa, pipa baja diameter $400 \mathrm{~mm}$ dengan bahan yang telah diuji secara mekanik bahan yang digunakan. Panjang pipa sesuai dengan kebutuhan (sampai tanah keras), didirikan diatas tanah dan kemudian diisi dengan beton mutu rendah $f c^{\prime} 10 \mathrm{MPa}$ dan akan dilanjutkan dengan beton mutu sedang $f c^{\prime} 20$ MPa dengan kedalaman $18 \mathrm{~m}$.

Untuk kedalaman pemancangan yang direncanakan tidak sesuai dengan kondisi lapangan, dikarenakan bagian abutment 1 memiliki 12 titik tiang pancang akan tetapi kedalaman tiang pancang yang memenuhi 18 m hanya 3 titik tiang pancang selebihnya dari titik pancang yang lain dengan kedalaman pancang mencapai $15 \mathrm{~m}$ sampai $17,83 \mathrm{~m}$ dikarenakan pemancangan sudah mencapai titik tanah keras. Sedangkan abutment 2 memiliki 12 titik tiang pancang.

Untuk mencatat hasil penumbukan dari Diesel Hammer maka digunakan kalendering agar mengetahui setiap satu kali penumbukan mendapatkan kedalam yang telah ditentukan akan tetapi dilapangan satu kali penumbukan dihasilkan $3-5 \mathrm{~cm}$. Sehingga mencapai 10 tumbukan dengan kedalam yang didapat $6 \mathrm{~cm}$. Untuk abutmen satu dan abutmen dua setiap satu tiang pancang mencapai 500 pukulan dan ada juga sampai 600 pukulan dengan kedalam yang berbeda-beda pula.

Pemancangan tiang pancang dilakukan dengan Diesel Hammer. Penumbukan dilakukan bagian atas tiang (top driving) yang telah dipasang khusus tiang berbentuk segi empat untuk penyambungan tiang pancang digunakan mesin las listrik. Untuk penumbukan tiang pancang dihentikan setelah ujung tiang pancang mencapai tanah keras, melalui control kalendering atau "final set" yang telah dihitung sebagaimana referensi rumus dari Diesel Pile Hammer.

\section{Perbandingan antara Rencana, Kondisi Lapangan dan Spesifikasi Teknis}

Untuk mengetahui suatu pekerjaan yang dilakukan memenuhi persyaratan teknis atau tidaknya, maka dibuat tabel perbandingan antara rencana, spesifikasi teknis dan kondisi dilapangan, agar mengetahui bahwa setiap item pekerjaan memenuhi persyaratan yang diinginkan oleh pihak yang bersangkutan. Perbandingan ini bisa kita lihat dari tabel dibawah ini:

Tabel 8. Hasil Perbandingan antara Rencana, Kondisi Lapangan dan Spesifikasi Teknis

\begin{tabular}{|c|c|c|c|c|}
\hline No & Rencana & Lapangan & Spesifikasi Teknis & Keterangan \\
\hline \multicolumn{5}{|c|}{ Pekerjaan Tanah Timbunan } \\
\hline 1. & $\begin{array}{l}\text { Uji kepadatan kering maksimum } \\
\text { dilakukan berdasarkan SNI 03- } \\
1742-1989\end{array}$ & $\begin{array}{l}\text { Uji } \quad \text { kepadatan } \begin{array}{r}\text { kering } \\
\text { maksimum }\end{array} \text { dilakukan } \\
\text { berdasarkan SNI 03-1742-1989 }\end{array}$ & $\begin{array}{l}\text { Untuk mengetahui uji } \\
\text { kepadatan kering maksimum } \\
\text { dapat dilakukan dengan SNI } \\
\text { 03-1742-1989. }\end{array}$ & Memenuhi \\
\hline 2. & $\begin{array}{l}\text { Berat isi kering }(M D D) 6 \% \text { Kadar } \\
\text { air }(O M C)\end{array}$ & $\begin{array}{l}\text { Berat isi kering }(M D D) \quad 6 \% \\
\text { Kadar air }(O M C)\end{array}$ & $\begin{array}{l}\text { Berat isi kering }(M D D) 6 \% \\
\text { max. Kadar air }(O M C)\end{array}$ & Memenuhi \\
\hline 3. & Liquid Limit $20 \%$ & Liquid Limit $31,02 \%$ & Liquid Limit max. $20 \%$ & Tidak Memenuhi \\
\hline 4. & Plastis index $25 \%$ & Plastis index $12,38 \%$ & Plastis index $25 \%$ & Tidak Memenuhi \\
\hline 5. & Nilai $C B R 6 \%$ & Nilai $C B R 6,57 \%$ & Nilai $C B R \min .6 \%$ & Memenuhi \\
\hline 6. & $\begin{array}{l}\text { Melakukan pemeriksaan kondisi } \\
\text { lapangan }\end{array}$ & $\begin{array}{ll}\text { Melakukan } & \text { pemeriksaan } \\
\text { kondisi lapangan }\end{array}$ & $\begin{array}{l}\text { Melakukan pemeriksaan } \\
\text { kondisi lapangan }\end{array}$ & Memenuhi \\
\hline
\end{tabular}


Sebelum dilakukan pengecoran Sebelum dilakukan pengecoran

1. penyedia jasa harus mengirim penyedia jasa harus mengirim design mix formula

2. Melakukan uji kekentalan beton segar (Test Slump)

3. Pengambilan benda uji

4. Melakukan uji kuat tekan beton

5. Pengujian menggunakan hammer test

Pekerjaan Baja Tulangan U 24 Polos dan U

1. Melakukan pengujian material pada baja tulangan U 24 dan U 32

Tulangan yang dingunkan U 24

2. dan U 32 sesuai dengan gambar kerja

Pekerjaan Baja Struktur BJ 50

1. Melakukan pengujian material pabrikasi

Melakukan uji kuat tekan beton

Pengujian menggunakan

hammer test

32 kerja
Sebelum dilakukan

pengecoran penyedia jasa

harus mengirim design mix formula

Melakukan uji kekentalan

beton segar (Test Slump)

Pengambilan benda uji

Melakukan uji kuat tekan

beton

Pengujian

hammer test

menggunakan

Melakukan pengujian material

pada baja tulangan $\mathrm{U} 24$ dan $\mathrm{U}$

32

Tulangan yang dingunkan U 24 Tulangan yang dingunkan U

dan U 32 sesuai dengan gambar 24 dan U 32 sesuai dengan gambar kerja

Material yang digunakan dari pabrikasi

Memenuhi

Memenuhi

Memenuhi

Memenuhi

Memenuhi

Memenuhi

Memenuhi

Memenuhi

Memenuhi
2. Material yang digunakan dari

Melakukan pengujian material
Material yang digunakan dari
pabrikasi

Melakukan pengujian material

Pemancangan Tiang Pancang Baja Diameter $400 \mathrm{~mm}$

1. Pemancangan dilakukan dengan alat berat Diesel Hammer

Pemancangan

dengan alat berat Diesel Hammer

Setiap penumbukan dikontrol

2. dengan kalendering yang mencatat setiap penumbukan

Setiap penumbukan tiang pancang

3. tidak boleh lebih dari $3 \mathrm{~cm}-5 \mathrm{~cm}$ masuknya satu pukulan
Setiap penumbukan dikontrol dengan kalendering yang mencatat setiap penumbukan Setiap penumbukan tiang pancang tidak boleh lebih dari 3 $\mathrm{cm}-5 \mathrm{~cm}$ masuknya satu pukulan
Pemancangan dilakukan

dengan alat berat Diesel Hammer

Setiap penumbukan dikontrol dengan kalendering yang mencatat setiap penumbukan

Setiap penumbukan tiang pancang tidak boleh lebih dari

$3 \mathrm{~cm}-5 \mathrm{~cm}$ masuknya satu pukulan
Memenuhi

Memenuhi

Memenuhi

Sumber: Data Olahan (2018)

\section{SIMPULAN}

Berdasarkan hasil pembahasan, maka dapat diambil kesimpulan sebagai berikut:

1. Pada pekerjaan tanah timbunan yang diterapkan dilapangan telah memenuhi pedoman teknis yaitu Spesifikasi Umum 2010 (Revisi 3) untuk Pekerjaan Konstruksi Jalan dan Jembatan Kementerian PUPR Ditjen Bina Marga baik dari pengujian laboratorium yang menghasilkan jenis tanah lempung berbutir halus dan mendapatkan $C B R$ $6,57 \%$, berat isi kering $(M D D)$ 1,547 Gr/Cc dan kadar air 18,10\%. Untuk memenuhi mutu pemadatan pada pekerjaan tanah timbunan yang sesuai Spesifikasi Umum 2010 (Revisi 3) untuk Pekerjaan Konstruksi Jalan dan Jembatan Kementerian PUPR Ditjen Bina Marga telah melakukan uji kepadatan lapangan dengan cara sand cone.

2. Sebelum pekerjaan beton mutu sedang $f_{c}^{\prime}{ }^{\prime} 20 \mathrm{MPa}$ dilakukan dilapangan terlebih dahulu dilakukan $D M F$ yang menjadi acuan untuk pengecoran, selain itu juga dilakukan beberapa pengujian yaitu: pengujian slump test dan kuat tekan. Pada setiap pengecoran beton, penyedia jasa membuat benda uji kubus dan diuji di umur 3 hari dan 7 hari. Mutu beton sedang yang dilaksanakan $f c^{\prime} 20$ MPa telah memenuhi Spesifikasi Umum 2010 (Revisi 3) untuk Pekerjaan Konstruksi Jalan dan Jembatan Kementerian PUPR Ditjen Bina Marga.

3. Untuk pekerjaan baja tulangan U 24 dan U 32 telah mengunakan material yang memenuhi Spesifikasi Umum 2010 (Revisi 3) untuk Pekerjaan Konstruksi Jalan dan Jembatan Kementerian PUPR Ditjen Bina Marga.

4. Baja Struktur BJ 50 di gunakan pada gelagar baja komposit kelas B dan hasil uji tariknya dengan nilai kuat tarik T$155,44 \mathrm{Kgf} / \mathrm{mm}^{2}$ dan T-2 55,06 Kgf $/ \mathrm{mm}^{2}$. Pengujian komponen baja struktur BJ $50 \mathrm{MPa}$ dilakukan di PT. Biro Klasifikasi Indonesia (Persero).

5. Pemancangan tiang pancang baja diameter $400 \mathrm{~mm}$ dengan bahan yang telah diuji secara mekanik. Kedalaman panjang pemancangan $18 \mathrm{~m}$ dimana $4 \mathrm{~m}$ kebawah digunakan beton $f_{c}$ ' $10 \mathrm{MPa}$ dan dilanjut lagi $5 \mathrm{~m}$ sampai ke permukaan tanah atau pile cap mengunakan beton bertulang dengan beton mutu sedang $f c^{\prime} 20 \mathrm{MPa}$. Untuk mencatat hasil penumbukan digunakan kalendering, satu kali penumbukan didapat kedalam $3 \mathrm{~mm}-6 \mathrm{~mm}$. Sehingga pada 10 tumbukan kedalam yang didapatkan adalah $6 \mathrm{~cm}$.

6. Alat yang digunakan untuk dilapangan sudah sesuai dengan mobilisasi yang telah dicantum dalam RAB (rencana 
Anggran Biaya) atau $B O Q$ (Bill of Quantity).

7. Dari tenaga ahli yang digunakan untuk menyelesaikan Pekerjaan Pembangunan Jembatan Rantau Kapas Tuo ini, baik dari Penyedia Jasa, Kontraktor dan konsultan Pengawas telah mengikuti Dokumen Lelang yang dipersyaratkan oleh dokumen pengadaan POKJA I (Satu) ULP Kabupaten Batanghari.

8. Dari penjelasan diatas dapat dilihat penerapan Manajemen Mutu ISO 9001:2000 (2005:13). Tentang prinsip Pendekatan Proses telah diterapkan dengan baik. Material, peralatan, dan tenaga kerja yang digunakan dalam pekerjaan telah sesuai Spesifikasi Umum 2010 (Revisi 3) untuk Pekerjaan Konstruksi Jalan dan Jembatan Kementerian PUPR Ditjen Bina Marga.

9. Dengan panduan Spesifikasi Umum 2010 (Revisi 3) untuk Pekerjaan Konstruksi Jalan dan Jembatan Kementerian PUPR Ditjen Bina Marga dan cara-cara teknis yang digunakan dalam pekerjaan ini mampu mengendalikan manajemen mutu yang diinginkan dan bisa meningkatkan kepuasan masyarakat atau pemakai produk yang dihasilkan oleh Pekerjaan Pembangunan Jembatan Rantau Kapas Tuo Tahun Anggaran 2017.

Setelah dilakukan analisa data-data yang diperoleh, dan membandingkan dengan kondisi lapangan yang telah dibahas maka penulis menyarankan hal-hal sebagai berikut:

1. Agar penyedia jasa dan konsultan pengawas mengikuti spesifikasi teknis yang menjadi pedoman pelaksanaan pekerjaan, maka dibuat formulir-formulir mengenai manajemen mutu, baik secara dokumen dan dilapangan dari hasil formulir tersebut akan dijadikan laporan yang bersifat baku.

\section{DAFTAR PUSTAKA}

Direktorat Jenderal Bina Marga Departemen PU RI, 1993, Panduan Pengawasan Pelaksanaan Jembatan, Bagian 1 Hal-hal Yang Berhubungan dengan Administrasi dan Prosedur, Bridge Managemen System, Jakarta.

Direktorat Jenderal Bina Marga Kementerian Pekerjaan Umum dan Perumahan Rakyat RI, 2014, Spesifikasi Umum 2010 (Revisi 3) untuk Pekerjaan Konstruksi Jalan dan Jembatan, Direktur Jenderal Bina Marga, Jakarta.

Efrianto, Wulfram I., 2005, Manajemen Proyek Konstruksi Edisi Revisi, Andi Offset, Yogyakarta.

Husen, Abrar, 2010, Manajemen Proyek, CV. Andi Offset, Serpong.

Prasetiyo, Dani, 2017, Laporan Akhir Supervisi Jembatan Rantau Kapas Tuo, PT. Sidlacom Engineer Consultant, Jambi.

Project Management Institute, 2000, A Guide To The Project Management Body Of Knowledge (PMBOK Guide)2000 Edition, Projeck Management Institute, Pennsylvania.

Tjiptono, Fandy, 1997, Prinsip-Prinsip Total Quality Service (TQS), Andi Offset, Yogyakarta.

Toruan, L. Rayendra, 2005, Panduan Penerapan Manajemen Mutu ISO 9001:2000, Penerbit PT. Elex Media Komputido (Kelompok Kompas Gramedia) dan LPJK, Jakarta.

Undang-Undang Republik Indonesia Nomor 2 Tahun 2017 Tentang Jasa Konstruksi.

Widiasanti, Irika dan Lenggogeni, 2013, Manajemen Konstruksi, PT. Remaja Posdakarya, Bandung. 